\title{
Morphological characteristics, dry matter production, and nutritional value of winter forage and grains under grazing and split nitrogen fertilization
}

\author{
Morfologia e valor nutricional da forragem e grãos de \\ cereais de inverno submetidos ao pastejo e ao \\ parcelamento da dose de nitrogênio
}

\author{
Loreno Egidio Taffarel ${ }^{1 *}$; Paulo Sérgio Rabello de Oliveira ${ }^{2}$; \\ Euclides Reuter de Oliveira ${ }^{3}$; Elaine Barbosa Muniz², Patricia Barcellos Costa ${ }^{2}$; \\ Eduardo Eustáquio Mesquita²; Jeferson Tiago Piano ${ }^{4}$; \\ Marcela Abbado Neres ${ }^{2}$; Poliana Ferreira da Costa ${ }^{5}$
}

\begin{abstract}
Morphological characteristics, dry matter production, and nutritional values of winter forage and grains were evaluated. This study was conducted from April 24, 2012 to November 7, 2013 in the Western Paraná State University (UNIOESTE), Marechal Cândido Rondon, Brazil. Pastures under one grazing and non-grazing conditions were evaluated under $120 \mathrm{~kg} \mathrm{~N} \mathrm{ha}^{-1}$ fertilization split into two $60 \mathrm{~kg} \mathrm{~N} \mathrm{ha}^{-1}$ treatments. Two pastures received $40 \mathrm{~kg} \mathrm{~N} \mathrm{ha}^{-1}$ three times. IPR 126 oat, BRS Tarumã wheat, and IPR 111 triticale were the test crops. Topdressing with 40 or $60 \mathrm{~kg} \mathrm{~N}^{-1}$ did not change morphological characteristics until $60 \mathrm{~d}$ after sowing. Pastures under non-grazing that received $120 \mathrm{~kg} \mathrm{~N}^{-1} \mathrm{a}^{-1}$ treatments were taller than the controls, whereas those under grazing that received 80 or $120 \mathrm{~kg} \mathrm{~N} \mathrm{ha}^{-1}$ presented with higher leaf production than did the controls. Total average dry matter (DM) production in 2012 and 2013 was, respectively, 5,275 $\mathrm{kg} \mathrm{ha}^{-1}$ and $6,270 \mathrm{~kg} \mathrm{ha}^{-1}$ for oat, $3,166 \mathrm{~kg} \mathrm{ha}^{-1}$ and 7,423 kg ha-1 for wheat, and 4,552 $\mathrm{kg} \mathrm{ha}^{-1}$ and 7,603 $\mathrm{kg} \mathrm{ha}^{-1}$ for triticale. Split $\mathrm{N}$ fertilization did not cause differences in the levels of crude protein (CP), neutral detergent fiber (NDF), and acid detergent fiber (ADF) in the forage. Nevertheless, increases in in vitro dry matter digestibility (IVDMD) were observed in oat and wheat receiving $60 \mathrm{~kg} \mathrm{~N} \mathrm{ha}^{-1}$ during the first graze. IVDMD did not change in oat, wheat, and triticale forages receiving 80 or $120 \mathrm{~kg} \mathrm{~N} \mathrm{ha}^{-1}$ during the second graze. Grazing did not affect the nutritional values of wheat and triticale grains, but reduced those of oat. Therefore, the results of the present study suggest that grazing lengthens the crop cycles, and so allow the staggered sowing of summer crops.
\end{abstract}

Key words: Avena sativa. Integrated crop-livestock system. Morphology. Triticum aestivum. X Triticosecale.

\footnotetext{
${ }^{1}$ Médico Veterinário, Dr., Universidade Estadual do Oeste do Paraná, UNIOESTE, Marechal Cândido Rondon, PR, Brasil. E-mail: loreno.taffarel@gmail.com

2 Profs., Centro de Ciências Agrárias, UNIOESTE, Marechal Cândido Rondon, PR, Brasil. E-mail: rabello.oliveira@hotmail.com; ebmuniz@yahoo.com.br; patriciabarc@hotmail.com; e-mesquita@bol.com.br; mabbadoneres@yahoo.com.br

3 Prof. Associado IV, Universidade Federal da Grande Dourados, UFGD, Dourados, MS, Brasil. E-mail: reutero@bol.com.br

${ }^{4}$ Doutor em Agronomia, UNIOESTE, Marechal Cândido Rondon, PR, Brasil. E-mail: jefersontpiano@hotmail.com

${ }^{5}$ Discente de Doutorado em Ciência e Tecnologia Ambiental, UFGD, MS, Brasil. E-mail: poliferreiradacosta@hotmail.com

* Author for correspondence
} 


\section{Resumo}

Avaliou-se características morfológicas, a produção de matéria seca e o valor nutricional da forragem e grãos de culturas de inverno. O trabalho foi desenvolvido de 24/04/2012 a 07/11/2013 na UNIOESTE. Foram avaliados os manejos sem pastejo e um pastejo (ambos com $120 \mathrm{~kg} \mathrm{ha}^{-1} \mathrm{de} \mathrm{N}$ em duas aplicações de $60 \mathrm{~kg} \mathrm{ha}^{-1}$ ) e dois pastejos com três aplicações de $\mathrm{N}$ de $40 \mathrm{~kg} \mathrm{ha}^{-1}$ nas culturas da aveia IPR 126, trigo BRS Tarumã e triticale IPR 111. A adubação em cobertura das doses de $40 \mathrm{ou} 60 \mathrm{~kg} \mathrm{ha}^{-1}$ de N não alteraram as características morfológicas até 60 dias após a semeadura. As parcelas sem pastejo e com $120 \mathrm{~kg} \mathrm{ha}^{-1} \mathrm{de} \mathrm{N}$ em duas doses de $60 \mathrm{~kg} \mathrm{ha}^{-1} \mathrm{de} \mathrm{N}$ cada tiveram, em 2012 e 2013, maior altura, enquanto as pastejadas com 80 ou $120 \mathrm{~kg} \mathrm{ha}^{-1}$ de $\mathrm{N}$ tiveram maior proporção de folhas. A média da produção total de MS em 2012 e 2013 respectivamente foi de: aveia 5275 e $6270 \mathrm{~kg} \mathrm{ha}^{-1}$; trigo 3166 e $7423 \mathrm{~kg} \mathrm{ha}^{-1}$; triticale 4552 e $7603 \mathrm{~kg} \mathrm{ha}^{-1}$. Na forragem não foram observadas diferenças nos teores de PB, FDN e FDA em função do parcelamento de $\mathrm{N}$, mas $60 \mathrm{~kg} \mathrm{ha}^{-1}$ de $\mathrm{N}$ aumenta a DIVMS na aveia e trigo no primeiro pastejo e 80 ou $120 \mathrm{~kg} \mathrm{ha}^{-1}$ de $\mathrm{N}$ não alteram a digestibilidade da forragem das três culturas no segundo pastejo. O pastejo não altera o valor nutricional de grãos de trigo e triticale, mas reduz nos grãos de aveia. Os ciclos das culturas são diferentes e aumenta com os pastejos e por isso permitem a semeadura escalonada com as culturas de verão.

Palavras-chave: Avena sativa. Sistema de integração lavoura pecuária. Morfologia. Triticum aestivum. $X$ Triticosecale.

\section{Introduction}

In Southern Brazil, sowing dual-purpose winter crops enables forage grazing for milk and meat production without affecting the physical characteristics of the soil provided that the grazing does not cause excessive defoliation both crop and soil are restocked properly. Forage regrowth is possible after one or two grazes with proper grazing management and climate and top-dressing fertilization to maintain proper conditions for grain and dry matter production under no-till farming (BARTMEYER et al., 2011).

Dual-purpose crops managed under an integrated crop-livestock system (ICLS) result in a greater variety of farming activities and revenue sources throughout the year, thereby decreasing risks due to climate conditions and price variations (LOPES et al., 2009). This system achieves production stability, productivity increases (SANTOS et al., 2011), and soil quality improvements over time (BALBINOT JUNIOR et al., 2009).

After the grazing season, winter cereals used for forage production in ICLS require a long growth period and a short reproductive cycle to produce high-quality grains (HASTENPFLUG et al., 2011).
It is difficult to establish a balance between the quantity and the proper quality of forage for animal consumption while minimizing the impact on soil condition and crops produced through succession (SANTOS et al., 2014; ASSMANN et al., 2014).

Nitrogen must be available during long growing seasons to promote increases in forage supply, support the absorption of other nutrients, and produce grains. Nitrogen stimulates root activity and growth, resulting in significant increases in dry matter yield and crude protein levels (ZAMARCHI et al., 2014).

There are several concerns about winter crops production using ICLS, such as its effects on agronomic characteristics, the bromatological quality of forage, oat, wheat, and triticale under grazing, and the inhibition of the dry matter production by grazing, which provides soil coverage in no-till sowing. Overall, grazing affects system dynamics (CARVALHO, 2013).

The aim of this study was to evaluate the morphological characteristics, the dry matter production, and the nutritional values of forage and three winter cereals under split nitrogen top dressing in ICLS management over a two-year period. 


\section{Materials and Methods}

This study was conducted from April 24, 2012 until November 7, 2013 in the "Professor Antônio Carlos dos Santos Pessoa" Experimental Farm (S $24^{\circ} 31^{\prime} 56.1^{\prime \prime} \mathrm{W} 54^{\circ} 01^{\prime} 10,3$ "; altitude $400 \mathrm{~m}$ ), which is the property of UNIOESTE in Marechal Cândido Rondon, PR, Brazil.

According to the Köppen classification, the regional climate is classified as Cfa mesothermal humid subtropical, with dry winters, hot summers, and rainfall evenly distributed throughout the year.
Average temperatures were $17-18^{\circ} \mathrm{C}$ during the coldest quarter, $28-29^{\circ} \mathrm{C}$ during the hottest quarter, and $22-23^{\circ} \mathrm{C}$ for the rest of the year. Total rainfall averages between 1,600 and 1,800 mm, with an average of $400-500 \mathrm{~mm}$ during the most humid quarter (CAVIGLIONE et al., 2000).

Climate data for the experimental period (Figure 1) was obtained using an automatic weather station located approximately $50 \mathrm{~m}$ from the experiment area. The weather station is the property of UNIOESTE (Marechal Cândido Rondon, Brazil).

Figure 1. Average, maximum, and minimum temperatures, and accumulated rainfall (mm) from April, 2012 to November, 2013.

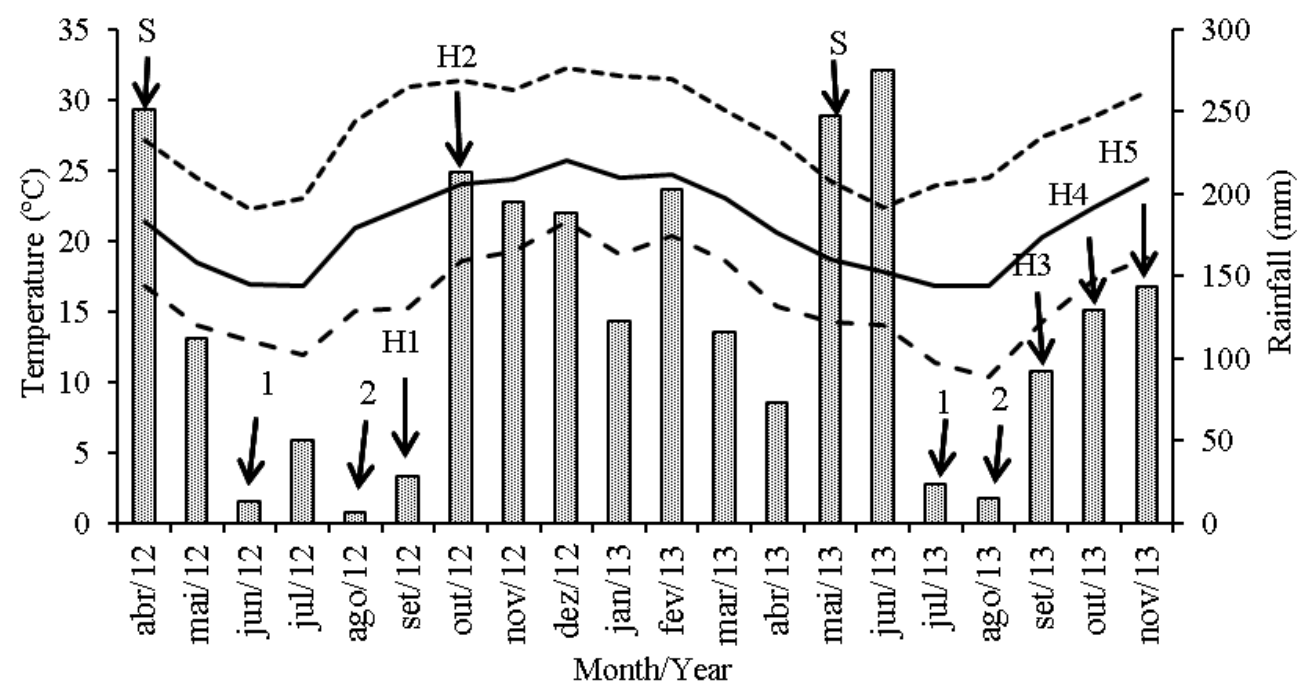

Rainfall (mm) — Avg. Temp ----- Max. Temp. - - - Min. Temp.

$\mathrm{S}$ = oat, wheat, and triticale sowing; 1 = first grazing; 2 = second grazing; $\mathrm{H} 1$ = non-grazed, once-grazed, and twice-grazed triticale harvest in 2012; H2 = non-grazed, once-grazed, and twice-grazed wheat and oat harvest in 2012; H3 = non-grazed triticale harvest; H4 = once- and twice-grazed triticale, and non-grazed and once-grazed wheat harvest; H5 = non-grazed, once-grazed, and twice-grazed oat, and twice-grazed wheat harvest.

The experimental area was under no-till farming management. Owing to its physicochemical characteristics (base saturation $(\mathrm{V} \%)<50 \%)$ liming was performed using 4 tons dolomitic lime to increase base saturation to $70 \%$. Liming was performed in April 2012 and November 2012, prior to sowing winter crops and soybean (summer) sowing, respectively.
The experimental design was random stripplotted blocks with four repetitions. Treatments consisted of three winter cereals (IPR 126 oat Avena sativa, IPR 111 triticale - X Triticosecale Wittmack, and BRS Tarumã wheat - Triticum aestivum L.) arranged in "A" strips $(10$ x $18 \mathrm{~m}$ vertically), and three soil treatments in "B" strips 
(5 x 30 m horizontally): no grazing (NG), one-graze season $(1 \mathrm{G})$, and two-graze seasons $(2 \mathrm{G})$. Plots included " $A$ " and "B" strip combinations $(5 \times 10$ $\mathrm{m})$. The total experimental area was $120 \mathrm{~m}$ (length) x $18 \mathrm{~m}$ (width). Each block size was $30 \mathrm{~m}$ (length) x $18 \mathrm{~m}$ (width) with 3-m-wide corridors and 9 plots with the following treatments:

(1) First forage evaluation (prior to the first grazing season): (a) oat, wheat, and triticale plots under $40 \mathrm{~kg} \mathrm{~N}^{-1}$, subjected to one of the two grazing seasons; (b) oat, wheat, and triticale plots under $60 \mathrm{~kg} \mathrm{~N} \mathrm{ha}^{-1} ; 50 \%$ of the plots were grazed;

(2) Second forage evaluation (prior to the second grazing season): (a) oat, wheat, and triticale plots under $80 \mathrm{~kg} \mathrm{~N} \mathrm{ha}^{-1}$, grazed once then subjected to a second grazing season; (b) oat, wheat, and triticale plots under $120 \mathrm{~kg} \mathrm{~N} \mathrm{ha}^{-1}$ and grazed once; (c) nongrazed oat, wheat, and triticale plots under $120 \mathrm{~kg}$ $\mathrm{N} \mathrm{ha}^{-1}$;
(3) Oat, wheat, and triticale plots: (a) nongrazed, $120 \mathrm{~kg} \mathrm{~N} \mathrm{ha}^{-1}$ split into two fertilizations; (b) two grazing seasons and $120 \mathrm{~kg} \mathrm{~N} \mathrm{ha}^{-1}$ split into two fertilizations; (c) two grazing seasons and 120 $\mathrm{kg} \mathrm{N} \mathrm{ha}{ }^{-1}$ split into three fertilizations.

The row spacing was $17 \mathrm{~cm}$, and a no-till farming (NTF) system was implemented. Base dressing fertilization was performed according to the recommendations of the Comissão de Química e Fertilidade do Solo do Rio Grande do Sul e Santa Catarina (2004), and Comissão Brasileira de Pesquisa de Trigo e Triticale (2011). Soil analysis results indicated high levels of $\mathrm{P}\left(>20 \mathrm{mg} \mathrm{dm}^{-3}\right)$ and

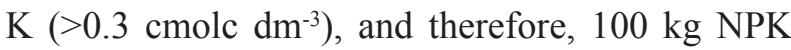
(8-20-20) ha-1 base dressing was added. The first top dressing was performed $30 \mathrm{~d}$ after sowing and the remaining fertilizations were performed during crop tillering (Table 1).

Table 1. Fertilization during sowing (kg ha-1), sowing dates, seed amount $\left(\mathrm{kg} \mathrm{ha}^{-1}\right)$, topdressing nitrogen fertilization ( $\mathrm{kg} \mathrm{ha}^{-1} \mathrm{~N}$ as urea); grazings dates, average forage height for input and output of dairy cows.

\begin{tabular}{|c|c|c|}
\hline \multirow{2}{*}{ Item } & \multicolumn{2}{|c|}{ Year } \\
\hline & 2012 & 2013 \\
\hline Lime $(\mathrm{ENP}=85 \%)$ & $2 \times 2$ ton & 0 \\
\hline Fertilizer 8-20-20 & 100 & 100 \\
\hline Sowing dates & April 24, 2012 & May 10, 2013 \\
\hline IPR 126 oat seeds & 60 & 60 \\
\hline BRS Tarumã wheat seeds & 90 & 90 \\
\hline IPR 111 triticale seeds & 40 & 60 \\
\hline $\mathrm{NG}^{*}$ and $1 \mathrm{G}^{*}$ plots top-dressing $\mathrm{N}$ fertilization & $2 \mathrm{x}$ de $60 \mathrm{~kg}$ & $2 \mathrm{x}$ de $60 \mathrm{~kg}$ \\
\hline $2 \mathrm{G}^{*}$ plots top-dressing $\mathrm{N}$ fertilization & $2 \mathrm{x}$ de $40 \mathrm{~kg}$ & $2 \mathrm{x}$ de $40 \mathrm{~kg}$ \\
\hline$N G, 1 G$ and $2 G$ plots first $N$ fertilization & $35 \mathrm{DAS}^{* *}$ & $35 \mathrm{DAS}$ \\
\hline $\mathrm{NG}, 1 \mathrm{G}$ and $2 \mathrm{G}$ plots second $\mathrm{N}$ fertilization & $65 \mathrm{DAS}$ & $65 \mathrm{DAS}$ \\
\hline $2 \mathrm{G}$ plots third $\mathrm{N}$ fertilization & 105 DAS & $105 \mathrm{DAS}$ \\
\hline First grazing dates (first evaluation) & 26 a 29/06 (63 DAS) & 08 a 10/07 (59 DAS) \\
\hline Second grazing dates (second evaluation) & 02 a 04/08 (100 DAS) & 14 a 15/08 (96 DAS) \\
\hline Canopy height under grazing & $30 \mathrm{~cm}$ & $30 \mathrm{~cm}$ \\
\hline Final height (destock) & $15 \mathrm{~cm}$ & $15 \mathrm{~cm}$ \\
\hline
\end{tabular}

*NG = no grazing; $1 \mathrm{G}=$ one-graze season; $2 \mathrm{G}=$ two-graze seasons $(2 \mathrm{G})$; DAS = days after sowing.

Two Holstein cows were supplied. They had an average weight of $663 \mathrm{~kg}$ and produced milk at an average of $25 \mathrm{~L} / \mathrm{d}$. The average plant canopy height $(\mathrm{ACH}$; average of three points) and stem length
(SL; obtained from the average length of 10 stems) were measured prior to grazing (first and second samplings) using a millimeter ruler. 
The dry matter production per hectare (DMP $\mathrm{ha}^{-1}$ ) and the nutrient output of the forage were estimated using the square frame method (Salman et al., 2006). Sampling was performed twice per experimental unit using a $0.25-\mathrm{m}^{2}$ metallic frame $5 \mathrm{~cm}$ above ground level. Samples were labeled, packed in paper bags, weighed, and then dried in a forced ventilation oven at $55^{\circ} \mathrm{C}$ for $72 \mathrm{~h}$.

The total forage DMP was obtained from the sum of the DMP for the respective treatment in the first and second evaluations then converted into DMP $\mathrm{ha}^{-1}$. The sampling dates for each year are listed in Table 1.

After drying, the forage and grain samples were ground in a Wiley mill equipped with a 30 mesh $(0.595$ $\mathrm{mm}$ ) sieve and then packed in properly identified plastic bags for the evaluation of dry matter (DM), crude protein $(\mathrm{CP})$, mineral matter $(\mathrm{MM})$, ether extract (EE), neutral detergent fiber (NDF), acid detergent fiber (ADF), lignin (LIG) through lignin sequencing using sulfuric acid, cellulose (CEL), and hemicellulose (HEM) (AOAC, 1990; VAN SOEST et al., 1991; SILVA; QUEIROZ, 2009).

In vitro dry matter digestibility (IVDMD) was determined using Tilley and Terry's method (1963), which was modified according to Santos et al. (1997). The analyses were performed in the Animal Nutrition and Bromatology Laboratory of the Federal University of Grande Dourados (UFGD) (Dourados, MS, Brazil).

The data were subjected to analysis of variance (ANOVA), and the averages for the different crop managements were compared using Tukey's test at 5\% probability, with SISVAR software (FERREIRA, 2011).

\section{Results and Discussion}

No differences in stem height or length were found between the 40 and $60 \mathrm{~kg} \mathrm{~N} \mathrm{ha}^{-1}$ treatments in the first evaluations (prior to the first grazing) in 2012 and 2013 (Figure 2). In the second 2012 evaluation, the stem height and length were greater in the nongrazed plots that received $120 \mathrm{~kg} \mathrm{~N} \mathrm{ha}^{-1}$ split into two fertilizations than in the grazed IPR 126 oat or triticale plots receiving two- or three-stage split fertilizations (120 and $80 \mathrm{~kg} \mathrm{~N} \mathrm{ha}^{-1}$ ). Nevertheless, no stem size differences were observed for BRS Tarumã wheat. In 2013, stem heights were greater on grazed plots than on non-grazed plots. No stemsize differences were observed across the $\mathrm{N}$ doses on grazed plots for either experimental year (Figure. 2).

These results are probably explained by the lower rainfall that occurred in May $(112 \mathrm{~mm})$ and June (13 mm), 2012; $247.8 \mathrm{~mm}$ and $275.6 \mathrm{~mm}$ rainfall occurred, respectively, in the same months in 2013. The height of BRS Tarumã wheat was especially affected. The average height of IPR 126 oat (Figure. 2) in the first evaluation was greater than the $27.75 \mathrm{~cm}$ obtained by Neres et al. (2012a). In the second evaluation, the same authors reported an average height of $39.77 \mathrm{~cm}$, which is similar to the results for 2012 and greater than those for 2013 in this present study. Mariani et al. (2012) reported a height of $19 \mathrm{~cm}$ for BRS Tarumã wheat, which is lower than those obtained for the first evaluations of 2012 and 2013 in this present study. Nevertheless, in the second evaluation, we obtained a height of $28 \mathrm{~cm}$. The expected average canopy height for IPR 111 triticale is $99 \mathrm{~cm}$ with a range between 81 and $110 \mathrm{~cm}$ (SILVA et al., 2006). The $75.9 \mathrm{~cm}$ height found for IPR 111 triticale in 2012 is explained by the water limitations that occurred during the growing season and reproductive cycle (Figure 1).

The stem lengths of IPR 126 oat prior to the first grazing (first evaluation) was $19 \mathrm{~cm} 63$ days after sowing (DAS) in 2012 and $15 \mathrm{~cm} 59$ DAS in 2013. In the second evaluation of plots receiving 80 and $120 \mathrm{~kg} \mathrm{~N} \mathrm{ha}^{-1}$, prior to the second grazing, the heights were $17.5 \mathrm{~cm}$ and $20.6 \mathrm{~cm}$ in 2012, and $10.8 \mathrm{~cm}$ and $10.6 \mathrm{~cm}$ in 2013 . On non-grazed plots, the heights were $40 \mathrm{~cm}$ in 2012 and $19.5 \mathrm{~cm}$ in 2013 (Figure 2). These results are similar to those obtained for grazed plots by Neres et al. (2012a). 
Figure 2. Canopy height $(\mathrm{cm})$, stem length $(\mathrm{mm})$, and leaves/stem ratio of IPR 126 oat, BRS Tarumã wheat, and IPR 111 triticale crops under 40 and $60 \mathrm{~kg} \mathrm{~N} \mathrm{ha}^{-1}$ fertilization prior to first graze, $120 \mathrm{~kg} \mathrm{~N}$ ha $^{-1}$ prior to second graze, and $120 \mathrm{~kg} \mathrm{~N} \mathrm{ha}^{-1}$ under non-grazing condition in 2012 and 2013.

First Evaluation
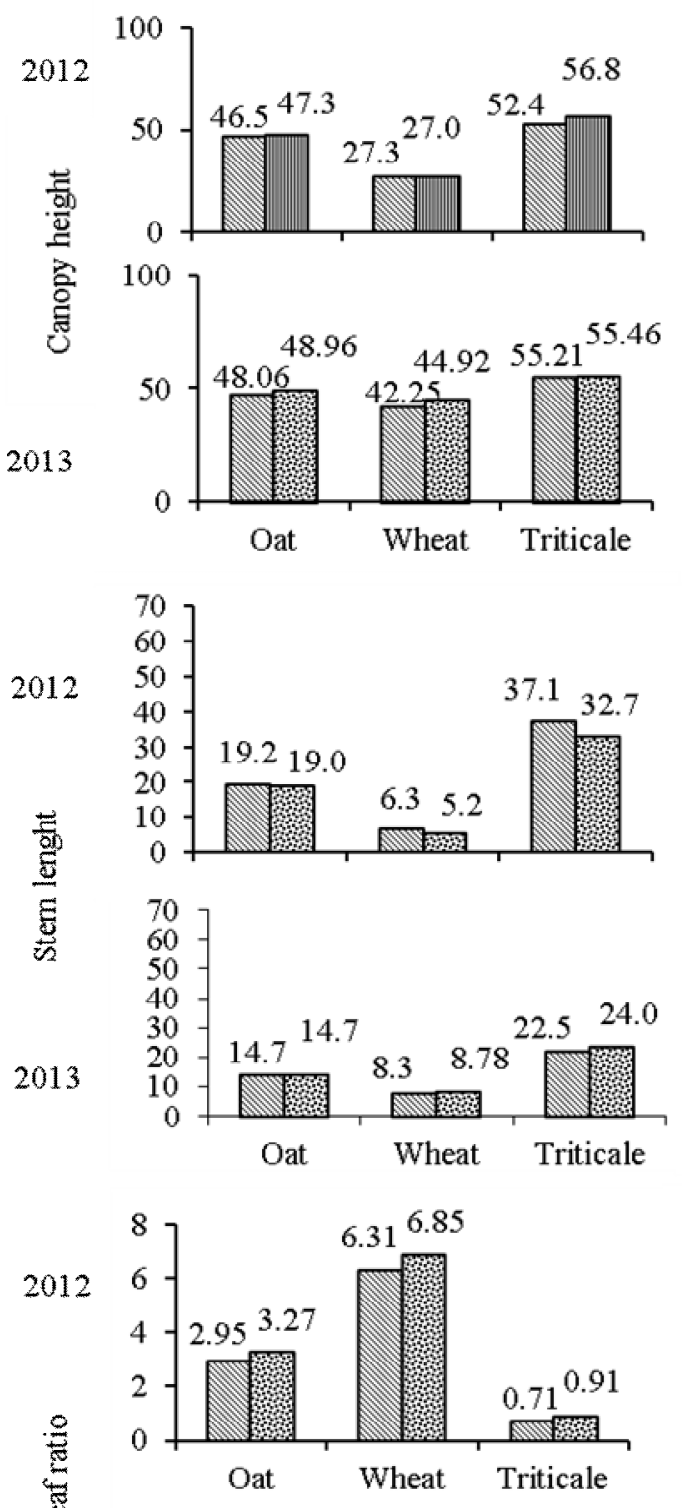

$\frac{\mathscr{E}}{\mathrm{E}}$

2013

1.861 .34
Second Evaluation
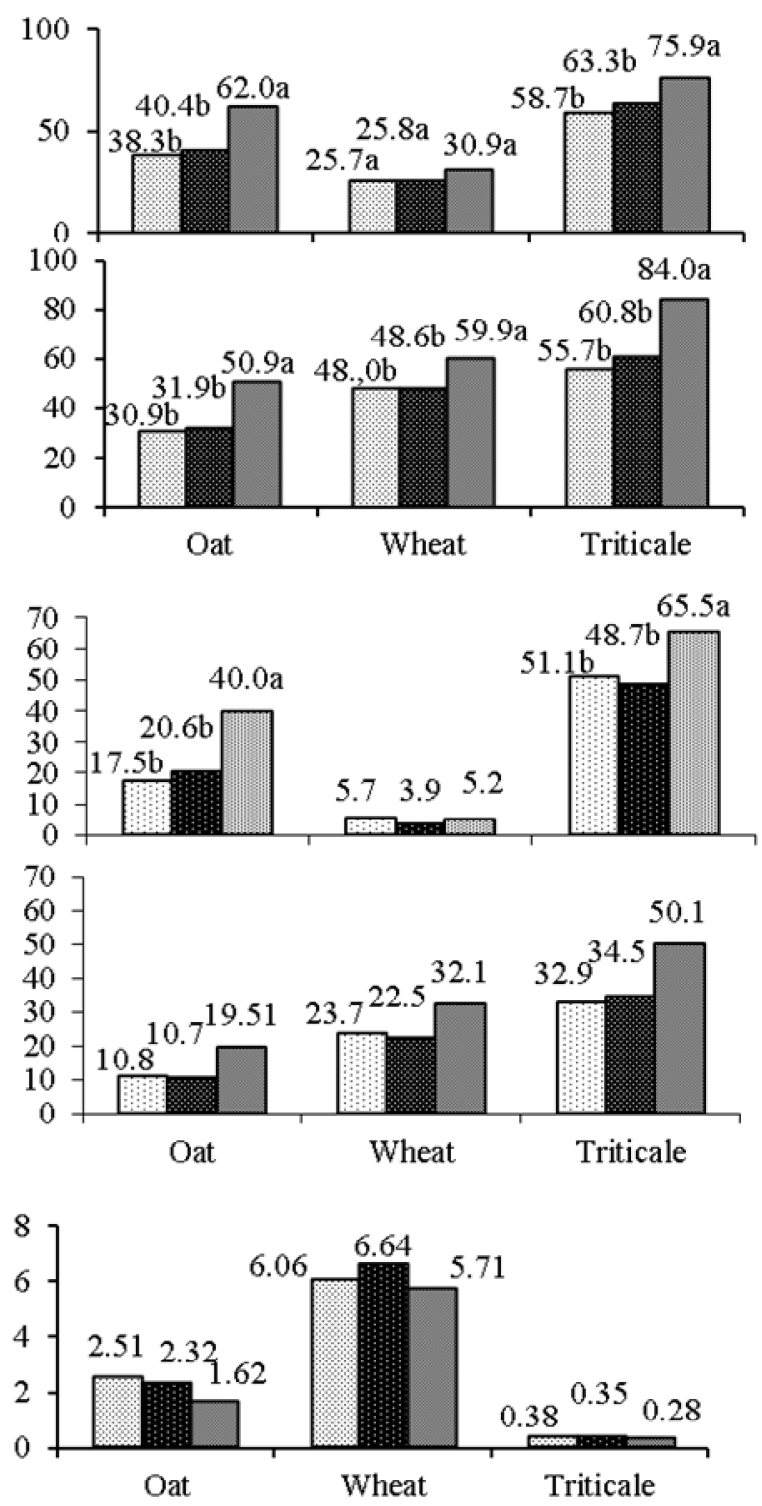

$40 \mathrm{~kg} \mathrm{ha}^{-1} \mathrm{~N}$ prior to first graze

V.? $60 \mathrm{~kg} \mathrm{ha}^{-1} \mathrm{~N}$ prior to first graze

$\square 80 \mathrm{~kg} \mathrm{ha}^{-1} \mathrm{~N}$ prior to second graze

$120 \mathrm{~kg} \mathrm{ha}^{-1} \mathrm{~N}$ once graze

$120 \mathrm{~kg} \mathrm{ha}^{-1} \mathrm{~N}$ non-grazed 
The stem lengths of BRS Tarumã wheat were $6.3 \mathrm{~cm}$ and $5.2 \mathrm{~cm}$ in 2012 and $8.3 \mathrm{~cm}$ and 8.78 $\mathrm{cm}$ in 2013 for the 40 and $60 \mathrm{~kg} \mathrm{~N}^{-1}$ treatments, respectively. Stem lengths on grazed plots receiving 80 and $120 \mathrm{~kg} \mathrm{~N} \mathrm{ha}^{-1}$, and on non-grazed plots receiving $120 \mathrm{~kg} \mathrm{~N}^{-1}$ were $5.7 \mathrm{~cm}, 3.9 \mathrm{~cm}$, and $5.2 \mathrm{~cm}$ in 2012, and $23.7 \mathrm{~cm}, 22.5 \mathrm{~cm}$, and $32.1 \mathrm{~cm}$ in 2013, respectively Figure 2).

The stem lengths of IPR 111 triticale were 37.1 $\mathrm{cm}$ and $32.72 \mathrm{~cm}$ in 2012, and $22.5 \mathrm{~cm}$ and 24.0 $\mathrm{cm}$ in 2013, for the 40 and $60 \mathrm{~kg} \mathrm{~N} \mathrm{ha}^{-1}$ treatments, respectively. For plots grazed once and receiving 80 and $120 \mathrm{~kg} \mathrm{~N} \mathrm{ha}^{-1}$, and for non-grazed plots receiving $120 \mathrm{~kg} \mathrm{~N}^{-1}$, the stem lengths were 51.1 $\mathrm{cm}, 48.7 \mathrm{~cm}$ and $65.5 \mathrm{~cm}$ in 2012, and $32.9 \mathrm{~cm}, 34.5$ $\mathrm{cm}$ and $50.1 \mathrm{~cm}$ in 2013, respectively.

There is no information in the literature about the stem length of wheat and triticale 60-100 days after emergence, which is approximately the interval between the first and second grazing.

Figure 2 shows that, in terms of stem length, each crop responded differently to the $427.6 \mathrm{~mm}$ rainfall which occurred between April and July of 2012, and the $562.4 \mathrm{~mm}$ during the same period in 2013 (Figure 1). Triticale required less water than the other crops. The greater stem length indicates the end of the growing season, and is related to a lower leaf/stem ratio (LSR), and consequently to a lower crude protein (CP) level and higher neutral detergent fiber (NDF) and acid detergent fiber (ADF) levels (Tables 2 and 3). Thus, a higher LSR indicates a higher grazing tolerance, which facilitates plant access by animals and indicates a higher forage nutritional value (OLIVEIRA et al., 2015).

The lower LSR found in triticale (Figure 2) might explain the higher dry matter (DM) levels. Higher DM levels occur in non-grazed oat and wheat plots, which tend to present with lower LSR since grazing stimulates the regrowth of these crops. The LSR for IPR 126 oat was 4.55 and 3.45 for the first and second evaluations, respectively. These values were lower than those reported by Neres et al. (2012a). Nevertheless, the LSR of BRS Tarumã wheat in
2012 was similar to that reported by Meinerz et al. (2012) (4.46 and 2.17 in first and second harvests, respectively).

In the plots grazed during 2012, the LSR increased by an average of $49 \%$ in oat, $11.2 \%$ in wheat, and $30.3 \%$ in triticale (Figure 2). Defoliation stimulates the formation of new leaves, which, in turn, favors the production of higher-quality forage.

In the first evaluations of both years, dry matter production ( $\mathrm{kg} \mathrm{DM} \mathrm{ha}{ }^{-1}$ ) did not differ among treatments. In the second evaluation of 2012, higher DMP was found in non-grazed oat $(4,440 \mathrm{~kg}$ DM $\left.\mathrm{ha}^{-1}\right)$ and triticale $\left(4,540 \mathrm{~kg} \mathrm{DM} \mathrm{ha} \mathrm{k}^{-1}\right)$ plots than in grazed plots; Non-grazed wheat had 1,840 kg DM $\mathrm{ha}^{-1}$ and did not differ in this respect from grazed wheat (Figure 3). In the second evaluation of 2013, no differences in DMP were observed, due to increased rainfall from May to August (562.4 mm) relative to the same period in $2012(182.4 \mathrm{~mm})$. The higher rainfall in 2013 resulted in higher greater nitrogen uptake for dry matter production in 2013 (Figure 1). Henz et al. (2016) estimated DMP as follows: first harvest:DMP $=1436.85+3.931 * \mathrm{~N}$, $1,594 \mathrm{~kg} \mathrm{DM} \mathrm{ha}{ }^{-1}$, and $1,673 \mathrm{~kg} \mathrm{DM} \mathrm{ha}{ }^{-1}$, with 40 and $60 \mathrm{~kg} \mathrm{~N}^{-1} 6969 \mathrm{DAS}$; second harvest: $\mathrm{DMP}=1485.40+5.894 * \mathrm{~N}, 1,957 \mathrm{~kg} \mathrm{DM} \mathrm{ha}{ }^{-1}$, and $2,193 \mathrm{~kg} \mathrm{DM} \mathrm{ha}{ }^{-1}$ and 1,594 $\mathrm{kg} \mathrm{DM} \mathrm{ha}{ }^{-1}$, with 80 and $120 \mathrm{~kg} \mathrm{ha}^{-1} \mathrm{~N}$ fertilization 86 DAS. For the first grazing, the results were similar to the above in 2012 and lower than the above in 2013. For the second grazing, the results were lower than the above in both years.

The total DMP was determined from the sum of the averages for the first and second evaluations. No differences were observed among treatments in 2012 (Figure 3). Nevertheless, grazed plots presented with the highest DMP in 2013 (Figure. 3). The total average DMP or the average DMP for each crop in 2012 was: IPR 126 oat $=5,275 \mathrm{~kg} \mathrm{ha}^{-1}$; BRS Tarumã wheat $=3,166 \mathrm{~kg} \mathrm{ha}^{-1}$; and IPR 111 triticale $=4,552$ $\mathrm{kg} \mathrm{ha}^{-1}$. The average DMP in 2013 was: IPR 126 oat $=6,270 \mathrm{~kg} \mathrm{ha}^{-1}$; BRS Tarumã wheat $=7,423 \mathrm{~kg}$ $\mathrm{ha}^{-1}$; and IPR 111 triticale $=5,603 \mathrm{~kg} \mathrm{ha}^{-1}$. The total 
DMP for IPR 126 oat in both years were higher than the reported by Demétrio et al. (2012), regardless of management type.

Owing to the decreased rainfall in 2012, the total DMP found for IPR 126 oat exceeded that of BRS Tarumã wheat by $67 \%$ and IPR 111 triticale by $16 \%$. In 2013, wheat DMP surpassed oat DMP by $18 \%$ and triticale DMP by $21 \%$ because of the increased rainfall during the first 60 DAS (Figure 1).

In both years, treatments with 40 and $60 \mathrm{~kg} \mathrm{~N} \mathrm{ha}^{-1}$ (first evaluation) did not differ $(p>0.05)$ in terms of CP, MM, and EE levels (Table 2). In the second evaluation, grazed treatments had higher CP levels in 2012 and 2013, regardless of the $\mathrm{N}$ dosage ( 80 or $120 \mathrm{~kg} \mathrm{~N} \mathrm{ha}^{-1}$ ). The same results were obtained for MM in 2013. In 2012, cultures and managements did not differ in terms of MM and EE levels (Table 2 ). The higher $\mathrm{CP}$ levels found in grazed plots are associated with the increased leaf/stem ratio observed in them (OLIVEIRA et al., 2015).

The wheat CP levels (Table 2) observed in this present study were lower than those found by Menegol et al. (2012) in the State of Rio Grande do Sul (343.4 $\left.\mathrm{g} \mathrm{kg}^{-1}\right)$. Bartmeyer et al. (2011) reported $\mathrm{CP} / \mathrm{kg}$ DM between $330.2 \mathrm{~g} \mathrm{~kg}^{-1}$ and $131.6 \mathrm{~g} \mathrm{~kg}^{-1}$ in a study conducted using BRS 176 dual-purpose cultivar in the General Fields of the State of Paraná. Mariani et al. (2012) reported $\mathrm{CP} / \mathrm{kg} \mathrm{DM}$ in the range of $289 \mathrm{~g} \mathrm{~kg}^{-1}$ to $229 \mathrm{~g} \mathrm{~kg}^{-1}$ in BRS Tarumã during the first and second grazing, respectively. They also reported CP/ $\mathrm{kg}$ DM in the range of $266 \mathrm{~g}$ $\mathrm{kg}^{-1}$ and $234 \mathrm{~g} \mathrm{~kg}^{-1}$ for Agro Zebu black oat during the first and second grazing, respectively. Crude protein (CP) levels may change depending on the winter forage sowing season (SOARES et al., 2013).

No differences in NDF, ADF, or HEM (Table 3) were observed in either year among nongrazed treatments receiving 40 and $60 \mathrm{~kg} \mathrm{~N} \mathrm{ha}^{-1}$ fertilizations, or in the following treatments from the second evaluation: (a) grazed once, $80 \mathrm{~kg} \mathrm{~N} \mathrm{ha}^{-1}$; (b) grazed once, $120 \mathrm{~kg} \mathrm{~N} \mathrm{ha}^{-1}$; (c) non-grazed, $120 \mathrm{~kg}$ $\mathrm{N} \mathrm{ha}^{-1}$ (Table 3). These findings could be explained by the increases in the leaf/stem ratio observed in grazed pastures. Grazing reduces stem length and reduces the L/S ratio over time (CASTAGNARA et al., 2010). Stems have higher levels of NDF, $\mathrm{ADF}$, and their components (lignin, cellulose, and hemicellulose) than do leaves.

Mariani et al. (2012) reported NDF and ADF levels for Agro Zebu black oat and BRS Tarumã wheat similar to those of grazed treatments in this present study in 2012, but lower than those observed in this experiment in 2013. Menegol et al. (2012) reported lower NDF results for BRS Tarumã wheat grown in the State of Rio Grande do Sul than those in this experiment. In general, the CP, NDF, and ADF levels (Tables 2 and 3) found for BRS Tarumã wheat in this study are similar to those reported by Pitta et al. (2011) for an experiment conducted in the southwestern portion of the State of Paraná.

Soares et al. (2013) conducted a four-sowingseason experiment in Dois Vizinhos, PR, Brazil and reported increases in NDF in IPR 126 oat during the sowing season but a simultaneous decrease in NDF for BRS Tarumã wheat. The authors concluded that sowing season affects forage nutritional value and may guide the sowing of forage combinations that can stabilize the nutritional value of pastures during their growth cycle.

Neres et al. (2012a) and Henz et al. (2016) reported higher HEM (hemicellulose) levels in IPR 126 oat and BRS Tarumã wheat, respectively than those found in this present study. Hemicellulose is a group of compounds essential for plant cell wall formation (Farinas, 2011) and has variable digestibility (VAN SOEST, 1994).

Not all of the treatments presented with differences in LIG or CEL levels for both years (Table 4). The levels of LIG and CEL reported in this experiment are similar to those found by Neres et al. (2012a) in oat. Nevertheless, the levels of LIG in wheat reported in this study are higher than those found by Henz et al. (2016), who stated an average $50.3 \mathrm{~g} \mathrm{~kg}^{-1} \mathrm{DM}$. In the present study, similar CEL levels were obtained in 2012, and lower levels in 2013 (210.0 $\left.\mathrm{g} \mathrm{kg}^{-1} \mathrm{DM}\right)$. 
Figure 3. Dry matter production in first and second evaluations and total dry matter production ( $\left.\mathrm{kg} \mathrm{DM} \mathrm{ha}^{-1}\right)$ of forage treatments containing IPR 126 oat, BRS Tarumã wheat, and IPR 111 triticale under split top-dressing nitrogen fertilization and grazing and non-grazing managements.

First Evaluation

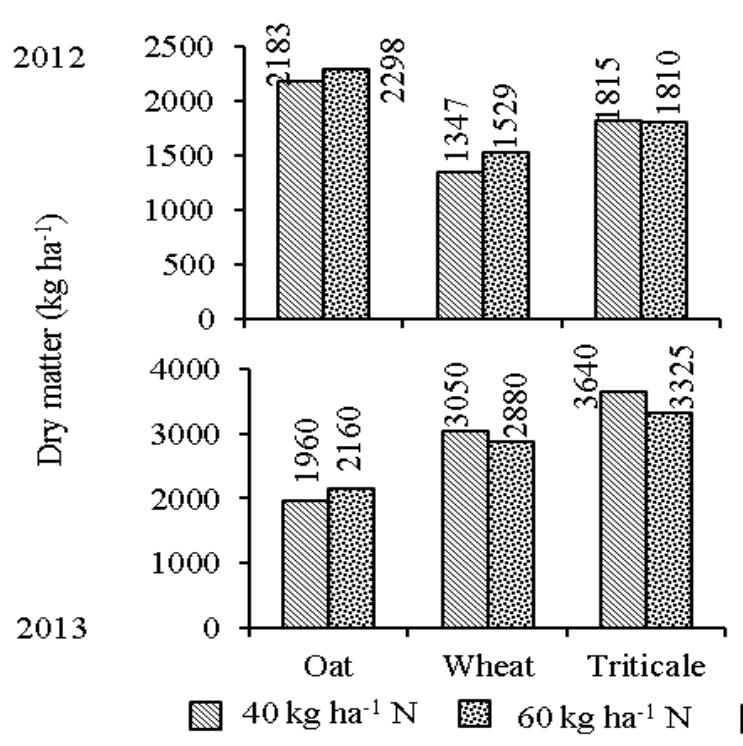

Second Evaluation
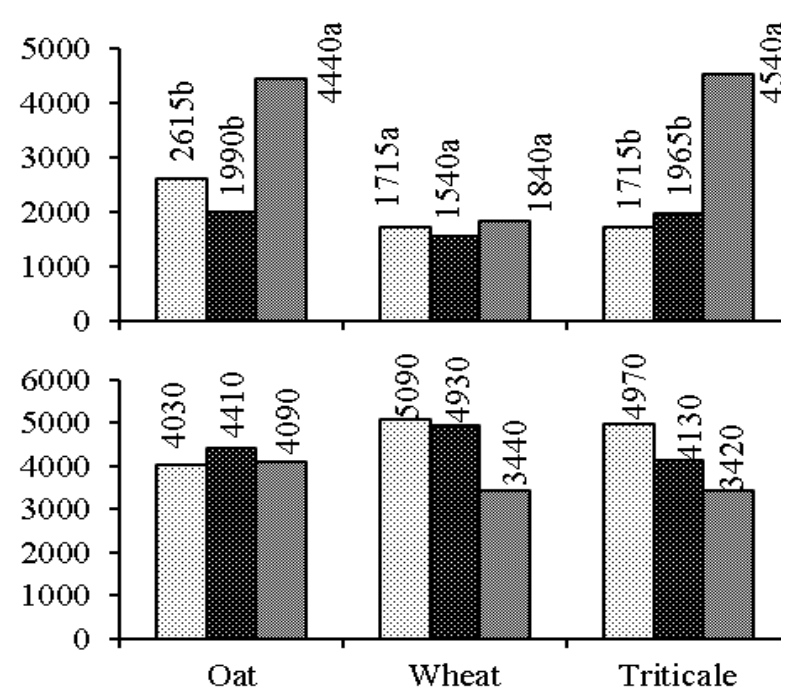

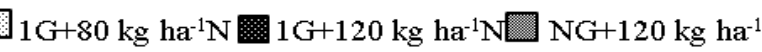

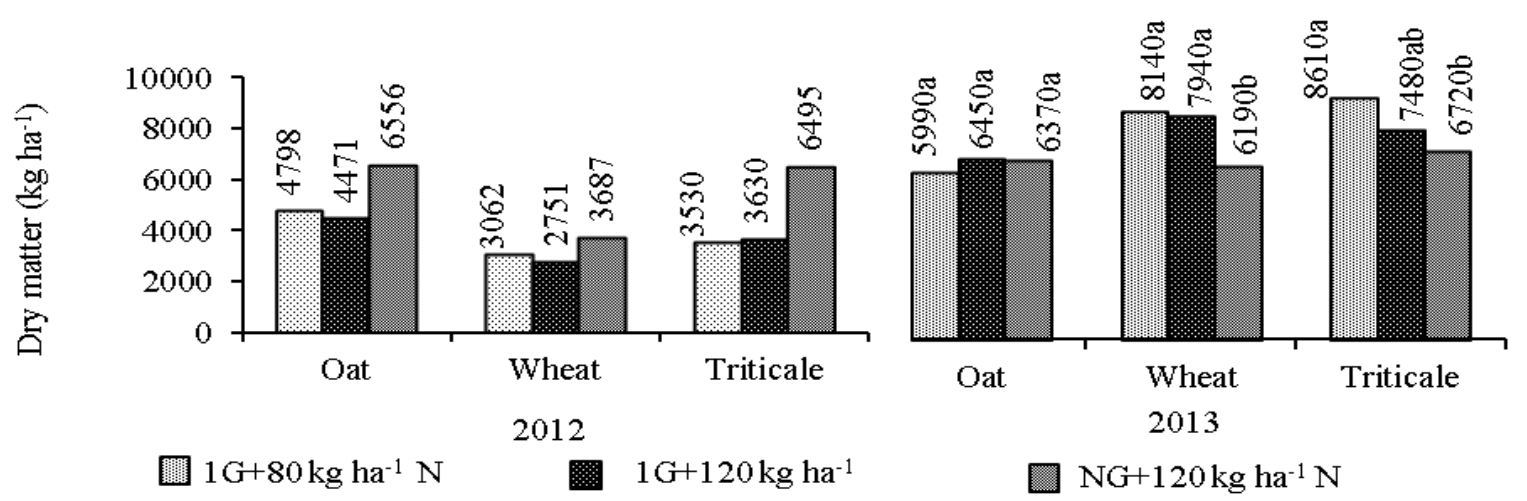

$* 1 \mathrm{G}=$ once grazed; $\mathrm{NG}=$ non-grazed. 
Table 2. Average levels ( $\left.\mathrm{g} \mathrm{kg}^{-1} \mathrm{DM}\right)$ of crude protein (CP), ash or mineral matter (MM), and ether extract (EE) in forage from IPR 126 oat, BRS Tarumã wheat, and IPR 111 triticale under grazing and non-grazing managements and split top-dressing nitrogen fertilizations in 2012 and 2013.

\begin{tabular}{|c|c|c|c|c|c|}
\hline \multirow{4}{*}{ Crop/Year } & \multirow{2}{*}{\multicolumn{2}{|c|}{$\begin{array}{l}\text { First Evaluation } \\
\text { (DAS: } 2012-63 \text { and 2013-59) } \\
\text { Nitrogen }\left(\mathrm{kg} \mathrm{ha}^{-1}\right)\end{array}$}} & \multicolumn{3}{|c|}{$\begin{array}{l}\text { Second Evaluation } \\
\text { (DAS: 2012-105 and 2013-98) }\end{array}$} \\
\hline & & & \multicolumn{3}{|c|}{ Nitrogen $\left(\mathrm{kg} \mathrm{ha}^{-1}\right)$ (Management) } \\
\hline & 40 & 60 & $80(1 \mathrm{G})$ & $120(1 \mathrm{G})$ & $120(\mathrm{NG})$ \\
\hline & \multicolumn{2}{|c|}{$\mathrm{CP}\left(\mathrm{g} \mathrm{kg}^{-1} \mathrm{DM}\right)$} & \multicolumn{3}{|c|}{$\mathrm{CP}\left(\mathrm{g} \mathrm{kg}^{-1} \mathrm{DM}\right)$} \\
\hline Oat/2012 & 187.2 & 184.1 & 191.8 & 187.6 & 162.9 \\
\hline Wheat/2012 & 206.6 & 197.7 & 209.1 & 216.9 & 201.9 \\
\hline Triticale/2012 & 172.3 & 175.8 & 165.6 & 165.2 & 122.4 \\
\hline CV1; CV2; CV3 & \multicolumn{2}{|c|}{$6.47 ; 15.04 ; 9.68$} & \multicolumn{3}{|c|}{$10.15 ; 13.55 ; 9.16$} \\
\hline Oat/2013 & 218.4 & 216.9 & 196.9 & 210.9 & 169.1 \\
\hline Wheat/2013 & 218.1 & 231.9 & 177.5 & 173.0 & 152.2 \\
\hline Triticale/2013 & 205.0 & 202.9 & 151.4 & 163.5 & 144.8 \\
\hline CV1; CV2; CV3 & \multicolumn{2}{|c|}{$8.90 ; 5.27 ; 3.94$} & \multicolumn{3}{|c|}{$3.85 ; 6.62 ; 8.38$} \\
\hline & \multicolumn{2}{|c|}{$\mathrm{MM}\left(\mathrm{g} \mathrm{kg}^{-1} \mathrm{DM}\right)$} & \multicolumn{3}{|c|}{$\mathrm{MM}\left(\mathrm{g} \mathrm{kg}^{-1} \mathrm{DM}\right)$} \\
\hline Oat/2012 & 108.8 & 130.3 & 95.1 & 101.8 & 90.2 \\
\hline Wheat/2012 & 114.6 & 116.4 & 99.8 & 97.2 & 96.4 \\
\hline Triticale/2012 & 107.3 & 113.2 & 80.2 & 80.9 & 78.1 \\
\hline CV1; CV2; CV3 & \multicolumn{2}{|c|}{$12.48 ; 16.79 ; 12.79$} & \multicolumn{3}{|c|}{$5.60 ; 8.27 ; 13.69$} \\
\hline Oat/2013 & 118.0 & 123.3 & 111.0 & 111.6 & 104.1 \\
\hline Wheat/2013 & 126.0 & 127.9 & 95.2 & 90.0 & 80.4 \\
\hline Triticale/2013 & 119.3 & 119.9 & 90.0 & 94.9 & 75.4 \\
\hline CV1; CV2; CV3 & \multicolumn{2}{|c|}{$4.15 ; 11.15 ; 3.62$} & \multicolumn{3}{|c|}{$8.84 ; 3.56 ; 4.69$} \\
\hline & \multicolumn{2}{|c|}{$\mathrm{EE}\left(\mathrm{g} \mathrm{kg}^{-1} \mathrm{DM}\right)$} & \multicolumn{3}{|c|}{$\mathrm{EE}\left(\mathrm{g} \mathrm{kg}^{-1} \mathrm{DM}\right)$} \\
\hline Oat/2012 & 34.9 & 32.2 & 40.8 & 40.9 & 34.2 \\
\hline Wheat/2012 & 34.9 & 36.3 & 41.0 & 42.0 & 37.1 \\
\hline Triticale/2012 & 30.9 & 31.2 & 30.7 & 28.6 & 27.8 \\
\hline CV1; CV2; CV3 & \multicolumn{2}{|c|}{$10.79 ; 15.27 ; 9.10$} & \multicolumn{3}{|c|}{$12.75 ; 11.60 ; 9.66$} \\
\hline Oat/2013 & 30.5 & 32.9 & $=$ & $=$ & $=$ \\
\hline Wheat/2013 & 29.7 & 39.7 & $=$ & $=$ & $=$ \\
\hline Triticale/2013 & 34.5 & 31.1 & $=$ & $=$ & $=$ \\
\hline CV1; CV2; CV3 & \multicolumn{2}{|c|}{$19.61 ; 9.53 ; 12.84$} & & $=$ & \\
\hline
\end{tabular}

* DAS: days after sowing; $1 \mathrm{G}=$ once-grazed; $2 \mathrm{P}=$ twice-grazed; $\mathrm{NG}=$ non-grazed. 40, 60, 80, or $120 \mathrm{~kg} \mathrm{~N}^{-1}$. Means followed by the same letter, capitalized in lines and non-capitalized in columns, did not significantly differ by Tukey's test at $5 \%$ probability.

In 2012, IVDMD for all crops were higher when $60 \mathrm{~kg} \mathrm{~N} \mathrm{ha}^{-1}$ than when $40 \mathrm{~kg} \mathrm{~N} \mathrm{ha}^{-1}$ was used. The second evaluation showed no differences in IVDMD among the oat and wheat treatments. Triticale presented with lower IVDMD in nongrazed plots receiving $120 \mathrm{~kg} \mathrm{~N}^{-1}$ than in grazed plots receiving 80 or $120 \mathrm{~kg} \mathrm{~N} \mathrm{ha}^{-1}$. There were no differences among the treatments in the first and second evaluations in 2013 (Table 4). The second evaluation of non-grazed treatments, however, presented lower digestibility than grazed treatments: IPR 126 oat $=4.32 \%(90.48 \% \times 86.57 \%)$; BRS Tarumã wheat $=8.62 \%(79.21 \% \times 72.38 \%)$; IPR 111 triticale $=9.83 \%(77.23 \% \times 69.64 \%)$.

The average oat IVDMD was $89.18 \%$, possibly due to relatively lower levels of NDF, ADF, LIG, and CEL (Table 4 - second evaluation). The average wheat IVDMD was $73.93 \%$, and that for triticale was $74.89 \%$. The digestibility of BRS Tarumã wheat in both years of this study was higher than 
that reported by Mariani et al. (2012). Neres et al. that for the 2012 data of this study but lower than (2012a) reported IPR 126 oat digestibility similar to that reported for 2013.

Table 3. Average levels ( $\mathrm{g} \mathrm{kg}^{-1} \mathrm{DM}$ ) of neutral detergent fiber (NDF), acid detergent fiber (ADF) and hemicellulose (HEM) in forages from IPR 126 oat, BRS Tarumã wheat, and IPR 111 triticale under grazing and non-grazing managements and split top-dressing nitrogen fertilization in 2012 and 2013.

\begin{tabular}{|c|c|c|c|c|c|}
\hline \multirow{4}{*}{ Crop/Year } & \multicolumn{2}{|c|}{$\begin{array}{l}\text { First Evaluation } \\
\text { (DAS: 2012-63 and 2013-59) }\end{array}$} & \multicolumn{3}{|c|}{$\begin{array}{l}\text { Second Evaluation } \\
\text { (DAS: 2012-105 and 2013-98) }\end{array}$} \\
\hline & \multicolumn{2}{|c|}{ Nitrogen $\left(\mathrm{kg} \mathrm{ha}^{-1}\right)$} & \multicolumn{3}{|c|}{ Nitrogen (kg ha-1 ${ }^{-1}$ (Management) } \\
\hline & 40 & 60 & $80(1 \mathrm{G})$ & $120(1 \mathrm{G})$ & $120(\mathrm{NG})$ \\
\hline & \multicolumn{2}{|c|}{$\mathrm{NDF}\left(\mathrm{g} \mathrm{kg}^{-1} \mathrm{DM}\right)$} & \multicolumn{3}{|c|}{$\mathrm{NDF}\left(\mathrm{g} \mathrm{kg}^{-1} \mathrm{DM}\right)$} \\
\hline Oat/2012 & 450.3 & 456.4 & 408.0 & 421.3 & 481.1 \\
\hline Wheat/2012 & 453.4 & 455.9 & 460.4 & 457.4 & 476.0 \\
\hline Triticale/2012 & 466.2 & 476.3 & 508.4 & 482.4 & 517.8 \\
\hline CV1; CV2; CV3 & \multicolumn{2}{|c|}{$3.27 ; 5.61 ; 2.83$} & \multicolumn{3}{|c|}{$6.92 ; 6.82 ; 7.05$} \\
\hline Oat/2013 & 521.0 & 516.8 & 512.8 & 506.0 & 525.0 \\
\hline Wheat/2013 & 544.9 & 561.7 & 585.8 & 582.3 & 634.4 \\
\hline Triticale/2013 & 595.5 & 594.4 & 633.4 & 588.3 & 642.1 \\
\hline \multirow[t]{2}{*}{ CV1; CV2; CV3 } & \multicolumn{2}{|c|}{$2.87 ; 4.14 ; 2.83$} & \multicolumn{3}{|c|}{$5.21 ; 6.48 ; 4.95$} \\
\hline & \multicolumn{2}{|c|}{$\mathrm{ADF}\left(\mathrm{g} \mathrm{kg}^{-1} \mathrm{DM}\right)$} & \multicolumn{3}{|c|}{$\mathrm{ADF}\left(\mathrm{g} \mathrm{kg}^{-1} \mathrm{DM}\right)$} \\
\hline Oat/2012 & 313.4 & 320.6 & 265.9 & 270.7 & 308.5 \\
\hline Wheat/2012 & 281.5 & 278.8 & 277.7 & 269.7 & 294.7 \\
\hline Triticale/2012 & 308.3 & 306.2 & 314.5 & 315.4 & 337.4 \\
\hline CV1; CV2; CV3 & \multicolumn{2}{|c|}{$5.09 ; 9.55 ; 2.73$} & \multicolumn{3}{|c|}{$8.88 ; 4.22 ; 8.11$} \\
\hline Oat/2013 & 363.7 & 386.0 & 366.9 & 328.7 & 341.8 \\
\hline Wheat/2013 & 379.7 & 367.1 & 372.8 & 361.4 & 370.9 \\
\hline Triticale/2013 & 383.4 & 382.0 & 383.1 & 365.9 & 389.5 \\
\hline \multirow{2}{*}{ CV1; CV2; CV3 } & \multicolumn{2}{|c|}{$6.31 ; 8.36 ; 8.89$} & \multicolumn{3}{|c|}{$6.92 ; 4.61 ; 6.16$} \\
\hline & \multicolumn{2}{|c|}{$\operatorname{HEM}\left(\mathrm{g} \mathrm{kg}^{-1} \mathrm{DM}\right)$} & \multicolumn{3}{|c|}{$\operatorname{HEM}\left(\mathrm{g} \mathrm{kg}^{-1} \mathrm{DM}\right)$} \\
\hline Oat/2012 & 136.9 & 135.7 & 142.1 & 150.6 & 172.6 \\
\hline Wheat/2012 & 171.9 & 177.1 & 182.6 & 187.7 & 181.3 \\
\hline Triticale/2012 & 157.9 & 170.1 & 193.8 & 167.0 & 180.4 \\
\hline CV1; CV2; CV3 & \multicolumn{2}{|c|}{$7.64 ; 13.95 ; 9.96$} & \multicolumn{3}{|c|}{$19.17 ; 19.41 ; 14.54$} \\
\hline Oat/2013 & 157.2 & 130.7 & 145.9 & 178.3 & 183.1 \\
\hline Wheat/2013 & 165.2 & 194.6 & 212.9 & 220.8 & 263.5 \\
\hline Triticale/2013 & 212.1 & 212.4 & 250.4 & 222.4 & 252.7 \\
\hline CV1; CV2; CV3 & \multicolumn{2}{|c|}{$11.82 ; 26.98 ; 16.93$} & \multicolumn{3}{|c|}{$16.91 ; 17.15 ; 15.95$} \\
\hline
\end{tabular}

One ton DM from winter crops (assuming an average $\mathrm{CP} / \mathrm{DM}$ of $188.80 \mathrm{~g} \mathrm{~kg}^{-1}$ ) provides approximately $188.80 \mathrm{~kg}$ CP. One ton Tifton 85 grass provides $120.00 \mathrm{~kg}$ CP (NERES et al., 2012b; TAFFAREL et al., 2014). Thus, winter crops provide an additional $68.80 \mathrm{~kg} \mathrm{CP}$, which is equivalent to $152.89 \mathrm{~kg}$ soybean meal (assuming a
$\mathrm{CP} / \mathrm{DM}$ of $\left.450 \mathrm{~g} \mathrm{~kg}^{-1} \mathrm{CP} / \mathrm{DM}\right)$. All three crops have high average digestibilities $(79.47 \%$ in 2012 , and $79.27 \%$ in 2013) - 36.4\% higher than the IVDMD for Tifton 85 (58.82\%) reported by Ribeiro and Pereira (2010). Therefore, nitrogen fertilization is warranted in forage raised for grazing or hay and silage. 
Table 4. Average levels ( $\mathrm{g} \mathrm{kg}^{-1} \mathrm{DM}$ ) of lignin (LIG), cellulose (CEL), and in vitro dry matter digestibility (IVDMD) in forages from IPR 126 oat, BRS Tarumã wheat, and IPR 111 triticale under grazing and non-grazing managements and split top-dressing nitrogen fertilization in 2012 and 2013.

\begin{tabular}{|c|c|c|c|c|c|}
\hline \multirow{4}{*}{ Crop/Year } & \multirow{2}{*}{\multicolumn{2}{|c|}{$\begin{array}{l}\text { First Evaluation } \\
\text { (DAS: 2012-63 and 2013-59) } \\
\text { Nitrogen }\left(\mathrm{kg} \mathrm{ha}^{-1}\right)\end{array}$}} & \multicolumn{3}{|c|}{$\begin{array}{l}\text { Second Evaluation } \\
\text { (DAS: 2012-105 and 2013-98) }\end{array}$} \\
\hline & & & \multicolumn{3}{|c|}{ Nitrogen $\left(\mathrm{kg} \mathrm{ha}^{-1}\right)+($ Management $)$} \\
\hline & 40 & 60 & $80(1 \mathrm{G})$ & $120(1 G)$ & $120(\mathrm{NG})$ \\
\hline & \multicolumn{5}{|c|}{ LIG $\left(\mathrm{g} \mathrm{kg}^{-1} \mathrm{DM}\right)$} \\
\hline Oat/2012 & 44.5 & 44.7 & 23.1 & 30.2 & 27.7 \\
\hline Wheat/2012 & 69.2 & 62.3 & 38.7 & 40.7 & 52.1 \\
\hline Triticale/2012 & 49.5 & 56.8 & 40.5 & 44.3 & 37.5 \\
\hline CV1; CV2; CV3 & \multicolumn{2}{|c|}{$15.66 ; 28.55 ; 19.17$} & \multicolumn{3}{|c|}{$30.38 ; 17.44 ; 17.96$} \\
\hline Oat/2013 & 44.0 & 53.2 & 65.0 & 59.2 & 47.9 \\
\hline Wheat/2013 & 60.1 & 61.0 & 68.2 & 61.3 & 60.0 \\
\hline Triticale/2013 & 60.5 & 63.4 & 63.6 & 57.4 & 63.8 \\
\hline \multirow[t]{2}{*}{ CV1; CV2; CV3 } & \multicolumn{2}{|c|}{$11.84 ; 18.68 ; 11.47$} & \multicolumn{3}{|c|}{$22.93 ; 16.96 ; 16.18$} \\
\hline & \multicolumn{5}{|c|}{$\mathrm{CEL}\left(\mathrm{g} \mathrm{kg}^{-1} \mathrm{DM}\right)$} \\
\hline Oat/2012 & 257.7 & 264.2 & 224.5 & 223.7 & 265.5 \\
\hline Wheat/2012 & 218.3 & 214.0 & 223.7 & 214.6 & 230.0 \\
\hline Triticale/2012 & 248.3 & 232.6 & 260.7 & 255.9 & 281.0 \\
\hline CV1; CV2; CV3 & \multicolumn{2}{|c|}{$5.69 ; 12.87 ; 4.48$} & \multicolumn{3}{|c|}{$8.91 ; 4.80 ; 8.31$} \\
\hline Oat/2013 & 302.8 & 312.7 & 278.0 & 243.7 & 276.1 \\
\hline Wheat/2013 & 295.8 & 283.1 & 282.7 & 277.4 & 290.1 \\
\hline Triticale/2013 & 301.5 & 299.0 & 294.3 & 283.6 & 301.3 \\
\hline CV1; CV2; CV3 & \multicolumn{3}{|c|}{$7.55 ; 7.89 ; 10.34$} & \multicolumn{2}{|c|}{$4.69 ; 5.16 ; 6.76$} \\
\hline \multicolumn{6}{|c|}{ IVDMD (\%) } \\
\hline Oat/2012 & $80.15 b$ & $86.50 \mathrm{a}$ & $85.00 \mathrm{a}$ & $79.25 \mathrm{a}$ & $83.25 \mathrm{a}$ \\
\hline Wheat/2012 & $82.69 \mathrm{~b}$ & $87.75 \mathrm{a}$ & $80.25 a$ & $84.25 \mathrm{a}$ & $79.00 \mathrm{a}$ \\
\hline Triticale/2012 & $88.14 \mathrm{a}$ & $86.25 \mathrm{a}$ & $76.25 \mathrm{a}$ & $81.00 \mathrm{a}$ & $66.5 \mathrm{~b}$ \\
\hline CV1; CV2; CV3 & \multicolumn{2}{|c|}{$6.31 ; 5.06 ; 2.89$} & \multicolumn{3}{|c|}{$5.50 ; 4.34 ; 4.23$} \\
\hline Oat/2013 & 90.45 & 90.81 & 89.55 & 91.42 & 86.57 \\
\hline Wheat/2013 & 87.09 & 89.29 & 79.59 & 78.83 & 72.38 \\
\hline Triticale/2013 & 87.45 & 86.12 & 75.88 & 78.58 & 69.64 \\
\hline CV1; CV2; CV3 & \multicolumn{2}{|c|}{$2.88 ; 2.65 ; 3.14$} & \multicolumn{3}{|c|}{$3.20 ; 2.80 ; 2.45$} \\
\hline
\end{tabular}

* DAS: days after sowing; $1 \mathrm{G}=$ once-grazed; $2 \mathrm{P}=$ twice-grazed; $\mathrm{NG}=$ non-grazed. 40, 60, 80, or $120 \mathrm{~kg} \mathrm{~N}^{-1}$. Means followed by the same letter, capitalized in lines and non-capitalized in columns, did not significantly differ by Tukey's test at $5 \%$ probability.

The bromatological analyses of the compounds in the grains evaluation did not reveal any differences in CP or EE levels (Table 5) in 2012 or 2013. There were also no differences in NDF, ADF, or HEM levels in 2013, or in IVDMD in 2012 (Table 6).

There were no significant effects of non-grazing, single-grazing, or double-grazing managements on CP levels. Del Duca et al. (1999) reported that grains from six winter cereals (white oat, black oat, triticale, barley, rye, and wheat) presented with higher CP levels in plots harvested twice than in plots harvested only once or not at all. These findings differ from those of this present study (Table 5).

Oat showed relatively higher MM levels in plots grazed twice in 2012 and 2013 (Table 5). The MM value for wheat was not affected by management types in 2012, but non-grazed wheat plots had relatively higher MM values in 2013. Triticale MM levels were not influenced by grazing in either year.

Del Duca et al. (1999) reported higher MM levels in wheat and triticale from plots grazed once 
or twice than in those from non-grazed plots. The authors did not report MM differences among the plot managements of white oat (UPF 4) or black oat.

Higher EE levels were observed in grains from non-grazed plots in 2012, but EE levels were relatively lower in non-grazed plots in 2013; for that year, the highest MM level was found in twicegrazed plots (Table 5). The highest EE levels for both years were found in oat. Del Duca et al. (1999) did not report any differences in MM levels among the non-grazed, once-grazed, or twice-grazed treatments of UPF 14 white oat, BR 4 triticale, IPF 55204 wheat, and PF 87451 wheat. Del Duca et al. (1999); Guarienti et al. (2001), and this present study reported similar average EE levels except for triticale in 2013, which was higher in this study than the others.

The CP levels in oat were $17.30 \%$ and $13.90 \%$ lower in single- and double-grazed plots, respectively. These differences were smaller in 2013. In 2012, the CP levels in wheat decreased by $1.92 \%$ and $22.63 \%$ in once- and twice-grazed plots, respectively. In 2013, the CP levels in wheat decreased by $6.75 \%$ and $14.36 \%$ in once and twicegrazed plots, respectively. In 2012, the CP levels in triticale increased by grains by $7.72 \%$ and $14.75 \%$ in once and twice-grazed plots, respectively. In 2013, the triticale CP levels fell by $20.9 \%$ and $19.98 \%$ in single- and double-grazed plots, respectively. The differences between the 2012 and 2013 CP values resulted from the fact that whereas the rainfall between June to September in 2012 was $99.2 \mathrm{~mm}$, it was $406.6 \mathrm{~mm}$ in the same period in 2013--an additional $307.4 \mathrm{~mm}$ relative to 2012 (Figure 1).

Oat and wheat grain $\mathrm{CP}$ are negatively affected by a single grazing, and even more so by a second grazing, regardless of climate conditions. These results differ from those of Fontaneli et al. (2011) who observed that among twenty wheat genotypes,
CP levels increased independently of grazing. The CP levels observed for triticale in 2012 are explained by its increased tolerance to water restriction (MORI et al., 2014).

$\mathrm{CP}$ levels in oat, wheat, and triticale in this present study surpassed those reported by Mori et al. (2014), regardless of management type. Oat CP levels in 2013 in the present study resembled those found by Marini et al. (2007), regardless of management type. Triticale CP levels were also higher than those reported by Zofia et al. (2011) and Bielski et al. (2015).

Marini et al. (2007) reported higher EE values and lower MM levels in oat than those observed in the present study. In the present study, MM levels were higher in 2012 and lower in 2013 than those reported by Guarienti et al. (2001) (14.6-19.5 g $\left.\mathrm{kg}^{-1} \mathrm{DM}\right)$. Nevertheless, our BRS Tarumã wheat EE levels were lower than those reported by these authors; levels ranged from 16.5 to $19.7 \mathrm{~g} \mathrm{~kg}^{-1} \mathrm{DM}$ among the four wheat varieties analyzed. In both years, MM levels in this study were similar to those found by Guarienti et al. (2001), but EE levels were relatively higher (15.3 $\left.\mathrm{g} \mathrm{kg}^{-1} \mathrm{DM}\right)$. The ether extract (EE) is composed of fats and other compounds and is the food component with the highest caloric value (SILVA; QUEIROZ, 2009).

Management type did not affect IVDMD ( $p>$ 0.05 ) in 2012. Nevertheless, IPR 126 oat grains from non-grazed plots presented had $38.60 \%$ and $22.27 \%$ higher IVDMD in 2012 and 2013, respectively, than did grains from once- and twice-grazed plots. These differences can be explained as follows: due to low rainfall during the grazing periods of 2012 and 2013 and the long growth cycle of oat, grain formation was significantly impaired, which in turn increased NDF, ADF, and HEM levels while reducing IVDMD. 
Table 5. Levels $\left(\mathrm{g} \mathrm{kg}^{-1} \mathrm{DM}\right)$ of crude protein $(\mathrm{CP})$, ash or mineral matter $(\mathrm{MM})$, and ether extract (EE) in grains from IPR 126 oat, BRS Tarumã wheat, and IPR 111 triticale under grazing and non-grazing managements and split topdressing nitrogen fertilization in 2012 and 2013.

\begin{tabular}{|c|c|c|c|c|c|c|}
\hline \multirow{3}{*}{ Crop/Year } & \multicolumn{3}{|c|}{ Management } & \multirow[b]{2}{*}{ CV1 } & \multirow[b]{2}{*}{ CV2 } & \multirow[b]{2}{*}{ CV3 } \\
\hline & $\mathrm{NG}$ & $1 \mathrm{G}$ & $2 \mathrm{G}$ & & & \\
\hline & \multicolumn{6}{|c|}{$\mathrm{CP}\left(\mathrm{g} \mathrm{kg}^{-1} \mathrm{DM}\right)$} \\
\hline Oat/2012 & 150.3 & 124.3 & 129.4 & & & \\
\hline Wheat/2012 & 244.8 & 240.1 & 189.4 & 15.31 & 21.69 & 18.26 \\
\hline Triticale/2012 & 173.5 & 186.9 & 199.1 & & & \\
\hline Oat/2013 & 150.4 & 155.4 & 148.6 & & & \\
\hline Wheat/2013 & 222.1 & 207.1 & 190.2 & 12.51 & 20.95 & 16.24 \\
\hline \multirow{2}{*}{ Triticale/2013 } & 216.7 & 171.4 & 173.4 & & & \\
\hline & \multicolumn{6}{|c|}{$\mathrm{MM}\left(\mathrm{g} \mathrm{kg}^{-1} \mathrm{DM}\right)$} \\
\hline Oat/2012 & $32.3 \mathrm{c}$ & $62.1 \mathrm{~b}$ & $78.2 \mathrm{a}$ & & & \\
\hline Wheat/2012 & $23.3 \mathrm{a}$ & $23.7 \mathrm{a}$ & $27.9 \mathrm{a}$ & 21.92 & 23.35 & 18.96 \\
\hline Triticale/2012 & $25.6 \mathrm{a}$ & $23.0 \mathrm{a}$ & $23.8 \mathrm{a}$ & & & \\
\hline Oat/2013 & $52.0 \mathrm{a}$ & $44.4 \mathrm{~b}$ & $43.9 \mathrm{~b}$ & & & \\
\hline Wheat/2013 & $12.9 \mathrm{~b}$ & $10.1 \mathrm{~b}$ & $29.5 \mathrm{a}$ & 15.15 & 14.03 & 13.46 \\
\hline \multirow[t]{2}{*}{ Triticale/2013 } & $22.6 \mathrm{a}$ & $19.1 \mathrm{a}$ & $20.5 \mathrm{a}$ & & & \\
\hline & \multicolumn{6}{|c|}{$\mathrm{EE}\left(\mathrm{g} \mathrm{kg}^{-1} \mathrm{DM}\right)$} \\
\hline Oat/2012 & 40.3 & 26.4 & 30.2 & & & \\
\hline Wheat/2012 & 15.5 & 11.7 & 10.1 & 17.21 & 22.78 & 42.51 \\
\hline Triticale/2012 & 23.0 & 10.2 & 16.6 & & & \\
\hline Oat/2013 & 33.5 & 33.2 & 31.7 & & & \\
\hline Wheat/2013 & 16.8 & 14.2 & 15.1 & 23.73 & 20.48 & 18.57 \\
\hline Triticale/2013 & 32.3 & 23.9 & 17.3 & & & \\
\hline
\end{tabular}

* $1 \mathrm{G}=$ once-grazed; $2 \mathrm{P}=$ twice-grazed; $\mathrm{NG}=$ non-grazed. Means followed by the same letter did not significantly differ by Tukey's test at $5 \%$ probability.

The digestibilities of wheat and triticale grains in vitro observed in this study are similar to those found by Beltranena and Zijlstra (2007). In a study conducted in UNESP - São Paulo State University, Botucatu, SP, Brazil, Tachibana et al. (2010) observed that triticale could completely substitute for corn as feed for Nile tilapia until day 100 after hatching without affecting performance or carcass characteristics. In an experiment conducted in Poland, Zofia et al. (2011) concluded that triticale can entirely replace barley as fodder for swine until day 92 (first stage) and for an additional $53 \mathrm{~d}$ (second stage), with beneficial effects on performance and carcass characteristics.
Mori et al. (2014) observed that the digestible energy available from grains for swine is as follows: oat $=2,769 \mathrm{kcal}$; wheat $=3,351 \mathrm{kcal}$; triticale $=3,278$ $\mathrm{kcal}$; corn $=3,460 \mathrm{kcal}$. The metabolizable energy available to swine from grains is as follows: oat = $2,716 \mathrm{kcal}$; wheat $=3,046 \mathrm{kcal}$; triticale $=3,031$ $\mathrm{kcal}$; corn $=3,381 \mathrm{kcal}$. These authors highlight that triticale might partially or completely replace corn as feed for broiler chicken and swine, depending on their age. The authors also describe the use of green forage, whole plant silage, whole grain, hay, or grain forms for ruminant feeding.

The values for total digestible nutrients (TDN) in oat, wheat, and triticale grains in each treatment were estimated using Chandler's equation (1990): $\mathrm{TDN}=81.41-(0.48 * \mathrm{ADF})$ (Table 7). 
Table 6. Levels ( $\mathrm{g} \mathrm{kg}^{-1} \mathrm{DM}$ ) of neutral detergent fiber (NDF), acid detergent fiber (ADF), and hemicellulose (HEM) in grains from IPR 126 oat, BRS Tarumã wheat, and IPR 111 triticale under grazing and non-grazing managements and split top-dressing nitrogen fertilization in 2012 and 2013.

\begin{tabular}{|c|c|c|c|c|c|c|}
\hline \multirow{2}{*}{ Crop/Year } & \multicolumn{3}{|c|}{ Manejo } & \multirow[b]{2}{*}{ CV1 } & \multirow[b]{2}{*}{ CV2 } & \multirow[b]{2}{*}{ CV3 } \\
\hline & $\mathrm{NG}$ & $1 \mathrm{G}$ & $2 \mathrm{G}$ & & & \\
\hline \multicolumn{7}{|c|}{$\mathrm{NDF}\left(\mathrm{g} \mathrm{kg}^{-1} \mathrm{DM}\right)$} \\
\hline Oat/2012 & $432.7 \mathrm{~b}$ & $662.6 \mathrm{a}$ & $651.1 \mathrm{a}$ & & & \\
\hline Wheat/2012 & $162.0 \mathrm{a}$ & $159.3 \mathrm{a}$ & $151.6 \mathrm{a}$ & 16.02 & 12.44 & 14.94 \\
\hline Triticale/2012 & $157.8 \mathrm{a}$ & $142.9 \mathrm{a}$ & $155.8 \mathrm{a}$ & & & \\
\hline Oat/2013 & 353.7 & 331.5 & 302.2 & & & \\
\hline Wheat/2013 & 94.6 & 106.4 & 83.2 & 16.29 & 20.01 & 15.08 \\
\hline Triticale/2013 & 137.7 & 164.8 & 167.0 & & & \\
\hline \multicolumn{7}{|c|}{$\mathrm{ADF}\left(\mathrm{g} \mathrm{kg}^{-1} \mathrm{DM}\right)$} \\
\hline Oat/2012 & $246.4 \mathrm{~b}$ & $377.2 \mathrm{a}$ & $335.2 \mathrm{a}$ & & & \\
\hline Wheat/2012 & $62.8 \mathrm{a}$ & $56.7 \mathrm{a}$ & $57.6 \mathrm{a}$ & 37.01 & 36.95 & 25.92 \\
\hline Triticale/2012 & $101.4 \mathrm{a}$ & $55.5 \mathrm{a}$ & $48.0 \mathrm{a}$ & & & \\
\hline Oat/2013 & 211.5 & 191.5 & 173.7 & & & \\
\hline Wheat/2013 & 29.2 & 26.9 & 32.6 & 12.15 & 14.12 & 17.53 \\
\hline Triticale/2013 & 57.2 & 50.6 & 45.2 & & & \\
\hline \multicolumn{7}{|c|}{$\mathrm{HEM}\left(\mathrm{g} \mathrm{kg}^{-1} \mathrm{DM}\right)$} \\
\hline Oat/2012 & $186.4 \mathrm{~b}$ & $285.1 \mathrm{a}$ & $274.1 \mathrm{~b}$ & & & \\
\hline Wheat/2012 & $100.3 \mathrm{a}$ & $99.4 \mathrm{a}$ & $97.2 \mathrm{a}$ & 17.52 & 15.56 & 13.23 \\
\hline Triticale/2012 & $99.2 \mathrm{a}$ & $90.0 \mathrm{a}$ & $101.5 \mathrm{a}$ & & & \\
\hline Oat/2013 & 142.2 & 139.8 & 128.5 & & & \\
\hline Wheat/2013 & 54.0 & 79.5 & 62.0 & 24.29 & 31.81 & 22.17 \\
\hline Triticale/2013 & 109.8 & 114.2 & 92.4 & & & \\
\hline \multicolumn{7}{|c|}{ IVDMD (\%) } \\
\hline Oat/2012 & 73.47 & 53.01 & 60.09 & & & \\
\hline Wheat/2012 & 92.27 & 88.78 & 89.58 & 4.32 & 6.81 & 10.33 \\
\hline Triticale/2012 & 88.94 & 88.36 & 93.88 & & & \\
\hline
\end{tabular}

* $1 \mathrm{G}=$ once-grazed; $2 \mathrm{P}=$ twice-grazed; $\mathrm{NG}=$ non-grazed. Means followed by the same letter did not significantly differ by Tukey's test at $5 \%$ probability.

Table 7. Levels of total digestible nutrients (TDN) in grains from IPR 126 oat, BRS Tarumã wheat, and IPR 111 triticale under grazing and non-grazing managements and split top-dressing nitrogen fertilization in 2012 and 2013.

\begin{tabular}{lllll}
\hline Crop/Year & Non-Grazed & Once-grazed & Twice-grazed & Mean \\
\hline Oat/2012 & 69.58 & 63.30 & 65.32 & 66.07 \\
Wheat/2012 & 78.40 & 78.69 & 78.65 & 78.58 \\
Triticale/2012 & 76.54 & 78.75 & 79.11 & 78.13 \\
\hline Oat/2013 & 73.07 & 72.22 & 71.26 & 72.18 \\
Wheat/2013 & 79.85 & 80.12 & 80.01 & 79.99 \\
Triticale/2013 & 79.24 & 78.98 & 78.66 & 78.96 \\
\hline
\end{tabular}

The estimated TDN for ground corn is animal species, the partial or total replacement approximately $82.01 \%$ (CLARINDO et al., 2008) of corn by winter cereals without affecting and its whole grain TDN may range from $77.21 \%$ - performance and with increases in gross margins is 78.97\% (BORGES et al., 2011). Thus, for some possible (BORGES et al., 2011). 


\section{Conclusions}

Fertilization with $120 \mathrm{~kg} \mathrm{~N}^{-1}$ split into three $40 \mathrm{~kg} \mathrm{~N} \mathrm{ha}^{-1}$ doses or two $60 \mathrm{~kg} \mathrm{~N} \mathrm{ha}^{-1}$ doses does not affect forage productivity until the first graze, regardless of climate conditions. Forage productivity decreases during the second graze if rainfall is low, regardless of the nitrogen dose applied.

The total dry matter production (DMP) of IPR 126 oat surpasses those of BRS Tarumã wheat and IPR 111 triticale when rainfall is low. Under proper rainfall conditions, wheat and triticale DMP may exceed that of oat.

Forage nutritional value is not affected by either 80 or $120 \mathrm{~kg} \mathrm{~N} \mathrm{ha}^{-1}$, or by grazing.

For IPR 126 oat and BRS Tarumã wheat, in vitro dry matter digestibility (IVDMD) increases with $60 \mathrm{~kg} \mathrm{~N} \mathrm{ha}^{-1}$ until the first graze. IVDMD does not change after the second graze or with 80 or $120 \mathrm{~kg}$ $\mathrm{N} \mathrm{ha}^{-1}$. Split nitrogen fertilization does not affect the digestibility of IPR 111 triticale.

Grazing does not change the nutritional value of BRS Tarumã wheat grains or IPR 111 triticale, but reduces that of IPR 126 oat.

Since different crops grow in different cycles, integrated crop-livestock systems can be established, and they can facilitate the succession planting of summer crops such as soybean and corn.

\section{References}

ASSMANN, T. S.; BORTOLLI, M. A.; ASSMANN, A. L.; SOARES, A. B.; PITTA, C. S. R.; FRANZLUEBBERS, A. J.; GLIENKE, C. L.; ASSMANN, J. M. Does cattle grazing of dual-purpose wheat accelerate the rate of stubble decomposition and nutrients released? Agriculture, Ecosystems and Environment, Amsterdam, v. 190, p. 37-42, 2014.

ASSOCIATION OF OFFICIAL ANALYTICAL CHEMISTS - AOAC. Official methods of analysis. 15. ed. Virginia: Arlington, 1990. 1117 p.
BALBINOT JUNIOR, A. A.; MORAES, A.; VEIGA, M.; PELISSARI, A.; DIECKOW, J. Integração lavourapecuária: intensificação de uso de áreas agrícolas. Ciência Rural, Santa Maria, v. 39, n. 6, p. 1925-1933, 2009.

BARTMEYER, T. N.; DITTRICH, J. R.; SILVA, H. A.; MORAES, A.; PIAZZETTA, R. G.; GAZDA, T. L.; CARVAlHO, P. C. F. Trigo de duplo propósito submetido a pastejo de bovino nos Campos Gerais do Paraná. Pesquisa Agropecuária Brasileira, Brasília, v. 46, n. 10, p. 1247-1253, 2011.

BELTRANENA, E.; ZIJLSTRA, R. Novel feed grains and pulses in Western Canada. Advances in Pork Production, Edmonton, v. 18, p. 229-236, 2007.

BIELSKI, S.; DUBIS, B.; BUDZYNSKI, W. Influence os nitrogen fertilization on the technological value of semi-dwarf grain winter triticale varieties alekto and gniewko. Polish Journal of Natural Sciences, Olsztyn, v. 30, n.4, p.325-336, 2015.

BORGES, C. A. A.; RIBEIRO, E. L. A.; MIZUBUTI, I. Y.; SILVA, L. D. F.; PEREIRA, E. S.; ZARPELON, T. G.; CONSTANTINO, C.; FAVERO, R. Substituição de milho grão inteiro por aveia preta grão no desempenho de cordeiros confinados recebendo dietas com alto grão. Semina: Ciências Agrárias, Londrina, v. 32, p. 20112020, 2011. Suplemento 1.

CARVALHO, P. C. F. Can grazing behaviour support innovations in grassland management? In: INTERNATIONAL GRASSLAND CONGRESS, 22. 2013, Sidnei. Proceedings... Sidnei: New South Wales Department of Primary, 2013. p. 1134-1148. Disponível em: $\quad<\mathrm{http} / /$ www.internationalgrasslands.org/files/igc/ publications/2013/proceedings-22nd-igc.pdf>. Acesso em: 08 out 2015 .

CASTAGNARA, D. D.; RÁDIS, A. C.; SOUZA, L. C.; SOUZA, F. H.; NERES, M. A.; MESQUITA, E. E. Características estruturais e produtivas da aveia preta comum em cinco idades de rebrota na região Oeste do Paraná. Cultivando o Saber, Cascavel, v. 3, n. 2, p. 116129, 2010.

CAVIGLIONE, J. H.; KIIHL, L. R. B.; CARAMORI, P. H.; OlIVEIRA, D. Cartas climáticas do Paraná: versão 1.0. Londrina: Instituto Agronômico do Paraná, 2000. CD-ROM. Disponível em: <http://www.iapar. $\mathrm{br} /$ modules $/$ conteudo/conteudo.php? conteudo $=677>$. Acesso em: 05 jan. 2015.

CHANDLER, C. Energy prediction of feeds by forage testing explored. Feedstuffs, Bloomington, v. 62, n. 36, p. $12,22,1990$. 
CLARINDO, R. L.; SANTOS, F. A. P.; BITTAR, C. M. M.; IMAIZUMI, H.; LIMA, N. V. A.; PEREIRA, E. M. Avaliação de fontes energéticas e protéicas na dieta de bovinos confinados em fase de terminação. Ciência Animal Brasileira, Goiânia, v. 9, n. 4, p. 902-910, 2008.

COMISSÃO BRASILEIRA DE PESQUISA DE TRIGO E TRITICALE. Informações técnicas para trigo e triticale - safra 2012. Dourados, MS: Embrapa Agropecuária Oeste, 2011. 204 p.

COMISSÃO DE QUÍMICA E FERTILIDADE DO SOLO - CQFS RS/SC. Manual de recomendações de adubação e calagem para os estados do Rio Grande do Sul e Santa Catarina. 10. ed. Porto Alegre: Sociedade Brasileira de Ciência do Solo, Núcleo Regional Sul, 2004. 394p.

DEL DUCA, L. de J. A.; GUARIENTE, E. M.; FONTANELI, R. S.; ZANOTTO, D. L. Influência de cortes simulando pastejo na composição química de grãos de cereais de inverno. Pesquisa Agropecuária Brasileira, Brasília, v.34, n.9, p.1607-1614, 1999.

DEMÉTRIO, J. V.; COSTA, A. C. T. da; OLIVEIRA, P. S. R. Produção de biomassa de cultivares de aveia sob diferentes manejos de corte. Pesquisa Agropecuária Tropical, Goiânia, v. 42, n. 2, p. 198-205, 2012.

FARINAS, C. S. A parede celular vegetal e as enzimas envolvidas na sua degradação. São Carlos: Embrapa Instrumentação, 2011. (Documentos, 54).

FERREIRA, D. F. Sisvar: a computer statistical analysis system. Ciência e Agrotecnologia, Lavras, v. 35, n. 6, p. 1039-1042, 2011.

FONTANELI, R. S.; FONTANELI, R. S.; SANTOS, H. P.; DREON, G. Rendimento e valor nutritivo de grãos de trigo de duplo propósito. Passo Fundo: Embrapa Trigo, 2011. Disponível em: <http://ainfo.cnptia.embrapa.br/ digital/bitstream/item/62618/1/2011 comunicadotecnico online306.pdf $>$. Acesso em: 20 mar. 2015.

GUARIENTI, E. M.; DEL DUCA, L. J.A.; FONTANELI, R. S.; ZANOTTO, D. L. Composição química dos principais cereais de inverno do Brasil. Pesquisa Agropecuária Gaúcha, Porto Alegre, v. 7, n. 1, p. 7-14, 2001.

HASTENPFLUG, M.; MARTIN, T.; BRAIDA, J. A.; BARBOSA, D. K.; ZIELINSKI, R. P.; REFATTI, R. Graind yeld of dual-purpose wheat cultivars as affected by nitrogen and cuttings. Bragantia, Campinas, v. 70, n. 4, p. 819-824, 2011.
HENZ, E. L.; ALMEIDA, P. S. G.; VELHO, J. P.; NÖRNBERG, J. L.; SILVA, L. D. F.; BACKES, T. R.; GUERRA, G. L. Dual purpose wheat production with diferente levels of nitrogen topdressing. Semina: Ciências Agrárias, Londrina, v. 37, n. 2, p. 1091-1100, 2016.

LOPES, M. L. T.; CARVALHO, P. C. F.; ANGHINONI, I.; SANTOS, D. T.; AGUINAGA, A. Q.; FLORES, J. P. C.; MORAES, A. Sistema de integração lavourapecuária: efeito do manejo da altura em pastagem de aveia preta e azevém anual sobre o rendimento da cultura da soja. Ciência Rural, Santa Maria, v. 39, n. 5, p. 14991506, 2009.

MARIANI, F.; FONTANELI, R. S.; VARGAS, L.; SANTOS, H. P.; FONTANELI, R. S. Trigo de duplo propósito e aveia preta após forrageiras perenes e culturas de verão em sistema de integração lavoura-pecuária. Ciência Rural, Santa Maria, v. 42, n. 10, p. 1752-1757, 2012.

MARINI, L. J.; GUTKOSKI, L. C.; ELIAS, M. C.; SANTIN, J. A. Qualidade dos grãos de aveia sob secagem intermitente em altas temperaturas. Ciência Rural, Santa Maria, v. 37, n. 5, p. 1268-1273, 2007.

MEINERZ, G. R.; OLIVO, C. J.; FONTANELI, R. S.; AGNOLIN, C. A.; HORST, T.; BEM, C. M. de. Produtividade cereais de inverno de duplo propósito na depressão central do Rio Grande do Sul. Revista Brasileira de Zootecnia, Viçosa, v. 41, n. 4, p. 873-882, 2012.

MENEGOL，D. R.; ZWIRTES, A. L.; BATTISTI, R.; BARONIO, C. A.; ROSA, G. M. Produtividade e qualidade da forragem e dos grãos produzidos por duas cultivares de trigo duplo propósito. Enciclopédia Biosfera, Goiânia, v. 8, n. 14, p. 788, 2012.

MORI, C. D.; NASCIMENTO JUNIOR, A.; MIRANDA, M. Z. Aspectos econômicos e conjunturais da cultura de triticale no mundo e no Brasil. Passo Fundo: Embrapa Trigo, abr., 2014 (Documento, 150).

NERES, M. A.; CASTAGNARA, D. D.; OLIVEIRA, P. S. R.; OLIVEIRA, E.; JOBIM, C. C.; TRES, T. T.; MESQUITA, E. E. IPR 126 white oat forage potential under free growth, cutting and grazing at two management heights. Revista Brasileira de Zootecnia, Viçosa, v. 41, n. 4, p. 889-897, 2012a.

NERES, M. A.; CASTAGNARA, D. D.; SILVA, F. B.; OLIVEIRA, P. S. R.; MESQUITA, E. E.; BERNARDI, T. C.; GUARIANTI, A. J.; VOGT, A. S. Características produtivas, estruturais e bromatológicas dos capins Tifton 85 e Piatã e do feijão-guandu cv. Super N, em cultivo singular ou em associação. Ciência Rural, Santa Maria, v. 42, n. 5, p. 862-869, 2012 b. 
OLIVEIRA, L. V.; FERREIRA, O. G. L.; PEDROSO, C. E. S.; COSTA, O. A. D.; ALONZO, L. A. G. Características estruturais de cultivares diploides e tetraploides de azevém. Bioscience Journal, Uberlância, v. 31, n. 3, p. 883-889, 2015.

PITTA, C. S. R.; SPARES, A. B.; ASSMANN, T. S.; ADAMI, P. F.; SARTOR, L. R.; MIGLIORINI, F.; SOLLENBERGER, L. E.; ASSMANN, A. L. Dualpurpose wheat grain and animal production under different grazing periods. Pesquisa Agropecuária Brasileira, Brasília, v. 46, n. 10, p. 1385-1391, 2011.

RIBEIRO, K. G.; PEREIRA, O. G. Valor nutritivo do capim-tifton 85 sob doses de nitrogênio e Idades de rebrotação. Revista Veterinária e Zootecnia, Viçosa, v. 17, n. 4, p. 560-567, 2010.

SALMAN, A. K. D.; SOARES, J. P. G.; CANESIN, R. C. Métodos de amostragem para avaliação quantitativa de pastagens. Porto Velho: Embrapa Rondonia, 2006 (Circular técnica, 84).

SANTOS, G. T.; ASSIS, M. A.; PETIT, H. V.; CECATO, U.; ZEOULA, L. M.; RIGOLON, L. P.; BRANCO, A. F.; DAMASCENO, J. C.; BETT, V. Chemical composition and in situ degradability of leucaena (Leucaena leucocephala) and desmodium (Desmodium ovalifolium) submitted at two conservation forms. Journal Dairy Science, Ontario, v. 80, p. 221-221, 1997. Supplement 1.

SANTOS, H. P. dos; FONTANELI, R. S.; CAIERÃO, E.; SPERA, S. T.; VARGAS, L. Desempenho agronômico de trigo cultivado para grãos duplo propósito em sistemas de integração lavoura-pecuária. Pesquisa Agropecuária Brasileira, Brasília, v. 46, n. 10, p. 1206-1213, 2011.

SANTOS, H. P. dos; FONTANELI, R. S.; PIRES, J. L. F.; BIAZUS, V.; VERDI, A. C.; VARGAS, A. M. Rendimento de grãos e características agronômicas de soja em função de pastagens perenes em sistema de plantio direto. Bragantia, Campinas, v. 73, n. 3, p.319326, 2014.

SILVA, A. C.; RIEDE, C. R.; POLA, J. N.; SHIOGA, P. S. Cultivar release - 'IPR 111' - Triticale cultivar. Crop Breeding and Applied Biotechnology, Viçosa, v. 6, p. 250-252, 2006.
SILVA, D. J.; QUEIROZ, A. C. Análise de alimentos: métodos químicos e biológicos. 3. ed. Viçosa: UFV, 2009. $235 \mathrm{p}$.

SOARES, A. B.; PIN, E. A.; POSSENTI, J. C. Valor nutritivo de plantas forrageiras anuais de inverno em quatro épocas de semeadura. Ciência Rural, Santa Maria, v. 43, n. 1, p. 120-125, 2013.

TACHIBANA, L.; GONÇALVES, G. S.; GUIMARAES, I. G.; FALCON, D. R.; BARROS, M. M.; PEZZATO, L. E. Substituição do milho pelo triticale na alimentação de tilápias-do-nilo. Revista Brasileira de Zootecnia, Viçosa, v. 39, n. 2, p. 241-246, 2010.

TAFFAREL, L. E.; MESQUITA, E. E.; CASTAGNARA, D. D.; OLIVEIRA, P. S. R.; OLIVEIRA, N. T. E.; GALBEIRO, S.; COSTA, P. B. Produção de matéria seca e valor nutritivo do feno do tifton 85 adubado com nitrogênio e colhido com 35 dias. Revista Brasileira de Saúde e Produção Animal, Salvador, v. 15, n. 3, p. 544560, jul./set. 2014.

TILLEY, J. M. A.; TERRY, R. A. A two stage technique for the in vitro digestion of forage crops. Journal of the British and Grassland Society, Nantwich, v. 18, p. 104111, 1963.

VAN SOEST, P. J. Nutritional ecology of the ruminant. 2. ed. Ithaca: Cornell University Press, 1994. 476 p.

VAN SOEST, P. J.; ROBERTSON, J. B.; LEWIS, B. A. Methods for dietary fiber, neutral detergente fiber and non-starch polysaccharides in relation to animal nutrition. Journal of Dairy Science, Champaign, v. 74, n. 10, p. 3583-3597, 1991.

ZAMARCHI, G.; PAVINATO, P. S.; MENEZES, L. F. G.; MARTIN, T. N. Silagem de aveia branca em função da adubação nitrogenada e pré-murchamento. Semina: Ciências Agrárias, Londrina, v. 35, n. 4, p. 2185-2196, 2014.

ZOFIA, T.; MARIA, O.; ALINA, J.; OLKOWSK, B. Feeding diets based on barley or triticale during fattening or high-meat pic pigs: effects on carcass characteristics and meat quality parameters. Acta Veterinaria, Beograd, v. 61, n. 1 , p. $67-75,2011$. 